of Wijde Bay and Ice Fiord. For this second region Sir Martin Conway has revived the old English whalers' name for Spitsbergen as a whole-King James Land.

Although the routes naturally did not extend over a very large area, considering the comparatively short time available for the exploration, Sir Martin Conway had a most interesting story to tell of a fight against difficulties, such as are presented to the explorer by few, even of the most remote regions of the world. His graphic descriptions, reinforced by the unusually fine representations of scenery supplied by Mr. Garwood's photographs, brought home to his hearers the chief characteristics of the country in a way which could only be surpassed by an actual visit to the scenes described. He also gave the meeting an in. structive study of the problems in physical geography which he thinks may be solved by his examination of the country. Garwood Land was first visited, a landing being effected at the foot of the Nordenskiöld Glacier, near the head of Klaas Billen Bay, one of the principal branches of Ice Fiord. The route led a little east of north, progress being difficult at first on account of the labyrinth of crevasses which intersect the glacier, and afterwards by reason of dense fog, and violent snowstorms. Particularly forcible was the lecturer's description of the white curtain of fog in which he and his companions were enwrapped for days together, and which in time caused a dazed feeling as if they had taken entire leave of the solid earth, and were floating in some unsubstantial nebula. The steep snow slopes entailed arduous labour in dragging the sledges, but after the fourth camp had been left some high snow domes were reached, from the summits of which views down broad valleys to the east and north were obtained, displaying a succession of plateau-fronts or bluffs of rock with névé both below and above them. The scenery, as seen by the evening light, was described as superb, the panorama being a glorious mass of colour. Returning to the coast, the travellers next proceeded to King's Bay on the west coast of the island in $79^{\circ} \mathrm{N}$., and thence penetrated inland into an interesting region of peaks and glaciers, several of the former being climbed. The principal mountain group is known as the Crowns, and lies between the two main branches of the King's Glacier. The peaks of this region present striking characteristics, well shown by the photographs displayed on the screen. The weather during this expedition was the most perfect imaginable. A week at Horn Sound, near the south end of the island, during which Mount Hedgehog, one of the highest peaks of the Hornsunds Tinder, was climbed, concluded the expedition. Dense fog was again encountered here, and the difficulties of the ascent were altogether out of proportion to the comparatively small elevation above sea-level, the extent of the actual climb (in the Alpinist's sense of the word) far exceeding that in the case of many of the more difficult summits of the Alps.

The principal geographical result of his second visit to Spitsbergen is, Sir Martin Conway considers, the discovery that neither of the districts visited, nor, in fact, any large part of the islands except New Friesland and North-East Land, is covered by an ice-sheet. As long as a flowing body of ice is contained within definite mountain ranges, it is a glacier, and the districts visited were both merely glacial and mountain areas. The im. portance of distinguishing clearly between the two types of icebearing country was strongly insisted upon by the lecturer, on account of the different natural processes to be seen at work in the two. The insignificance of the excavating action of ice was stated, perhaps, somewhat too uncompromisingly; but at any rate, as was shown by Sir Martin Conway, the forces acting on the land-surface beneath an ice-sheet are mainly conservative; while in a glacial region, the rock-faces which rise above the general surface are exposed to rapid denudation, and great developments of surface-form are going forward. The "eating-back" processs, recognised as a powerful agent of denudation in the case of rivers, was held to be equally effective in that of glaciers, although, of course, the result is due to aerial denudation, not to glacial erosion. The work of the glacier is to carry away the débris, the accumulation of which would otherwise arrest the process of denudation. Examples were given by the lecturer from the Bernese Oberland and the Karakoram Himalayas, in which the present surface features are, in his opinion, due to this eating-back process, which has entirely modified the original longitudinal drainage of the mountain masses. The great bluffs of the Oberland-the Eiger, Mettenberg, and Wetterhorn-show a striking resemblance to those of Spitsbergen's Sassendal.

At the close of the lecture Mr. E. J. Garwood gave some interesting details regarding the geological features of the country traversed, adding besides some graphic descriptions of the marvellous effects of colour, which give to the scenery of Spitsbergen such a unique character. Among the points touched upon was the presence in Spitzbergen, contrary to the formerly accepted idea, of a snow-line some $1200-1500$ feet above sea level. The contrast in the surface features above and below this line is most marked, the lower slopes showing as well. marked a denudation curve, with gullies due to flowing water, as may be seen in our own islands, while the upper regions show the abrupt rock-faces due to frost denudation. In the case of the Crowns this has acted along the vertical joint-planes of the carboniferous limestone rocks which form, as it were, a golden crown above the purple Devonian shales of which the more gradual, lower slopes are composed. Mr. Garwood also gave an account of the en-glacial streams, which often flow in a direction at right angles to that of the main valley, and which, on the retreat of the glacier might leave behind deposits similar to the kames and eskers which have so puzzled geologists in other countries. The remarkable ice-tunnels observed may be due, he thinks, to the arching up of ice-bridges over crevasses, when these are closed up by the movement of the glacier

A short discussion followed, devoted chiefly to the theory propounded by the lecturer with regard to the action of glaciers in modifying the surface features of a country.

Prof. Bonney, while allowing that the action supposed undoubtedly makes itself felt in certain cases, doubted the admissibility of a comparison between a plateau region like Spits. bergen and a region of narrow ridges like the Alps. The V. shaped Alpine valleys as a rule follow the lines of dip and strike, just as they do in unglaciated regions, while everywhere evidences of pre-glacial structure are to be found. From what we know of the climate of the Alps before the glacial epoch, we may conclude that in more remote times practically no glaciers existed. The characteristics noted by Sir M. Conway are, he considered, rather to be accounted for by the two distinct disturbances which have operated in the Bernese Oberland. The phenomenon adduced is, therefore, probably not more than a secondary cause in the moulding of the features of a country.

Mr. J. E. Marr doubted whether the side-glacier, shown in Sir M. Conway's diagram as hanging like a tear-drop on the mountain side, could be properly described as cutting back through the mountain wall behind it. It was important to keep clearly in view that the wearing-back process, even in the case of glaciers, was really due to the action of the weather at their head.

Sir Erasmus Ommanney expressed his high appreciation of the work done by Sir M. Conway and Mr. Garwood, and of the manner in which the results had been presented.

Dr. J. W. Gregory agreed in the main with Prof. Bonney, holding that though the phenomenon alluded to was no doubt a true cause, it was very uncertain whether it were a primary one.

Sir Henry Howorth considered that Sir M. Conway's theory had at least this in its favour - that it was consistent both with the laws of physics and of ice. He called attention to the change of climate which Spitsbergen has undergone in recent geological times, and to the fact of its belonging to the area of land rising in level around the North Pole.

\section{THE LAKE SUPERIOR IRON ORE REGION.}

$A T$ the present time the conditions and prospects of American competition in the iron trade call for very serious consideration. The aggregate value of iron and steel exported from the United States to Great Britain and the continent is now considerable, the official figures for the first nine months of 1897 giving a value of $45,693,000$ dollars, as compared with $34,549,000$ dollars for the corresponding period of 1896 . With this increase in the exports, there was a decrease in the imports from $16,361,000$ dollars in the first nine months of 1896 to $10,032,000$ dollars in the corresponding period of I897. The rapidly in. creasing intensity of American competition is thus apparent. The exportation of iron and steel is not a result merely of depressed conditions in the United States, but of lower cost of production, brought about by enforced economy in labour, by the great discoveries of cheaply worked ore, and by the increased

NO. 148 I, VOL. 57] 
efficiency of the mining and metallurgical plant in use. Undoubtedly the greatest advantage possessed by the United States is that in the Lake Superior region they have the most extensive supplies of cheap and rich iron ores known to exist. It is to the sudden development and unparalleled richness of these deposits that the United States chiefly owe their cheap pig iron. It is, therefore, a matter of extreme satisfaction that an authoritative description of these deposits has been prepared by $\mathrm{Mr}$. Horace V. Winchell for English readers in the form of an admirably illustrated monograph, ${ }^{1}$ covering seventy pages of the Transactions of the Federated Institution of Mining Engineers, and dealing with the history, geography, geology, and mining industry of the iron-ore region. Only forty years have elapsed since the first regular mining of iron ore was begun in the dis.

\begin{tabular}{|c|c|c|c|c|}
\hline Kange. & & Tuns. & & $\begin{array}{l}\text { Per cent. } \\
\text { of total. }\end{array}$ \\
\hline Mesabi & $\ldots$ & $3,082,973$ & $\ldots$ & 29.18 \\
\hline Marquette & $\ldots$ & $2,418,846$ & $\ldots$ & 22.89 \\
\hline Gogebic & $\ldots$ & $2,100,398$ & $\ldots$ & 19.88 \\
\hline Menominee & $\ldots$ & $\mathrm{I}, 763,235$ & $\ldots$ & 16.69 \\
\hline Vermilion & $\ldots$ & $1,200,907$ & $\ldots$ & I I 36 \\
\hline Total & . & $10,566,359$ & $\cdots$ & 100.00 \\
\hline
\end{tabular}

The iron-ore belts or ranges are situated chiefly in the States of Michigan and Minnesota. The beds occur in rocks of preSilurian, and probably of pre.Cambrian age, the determination of the geological age resting wholly on structural evidence. As to the genesis of the ores, there has been much speculation.

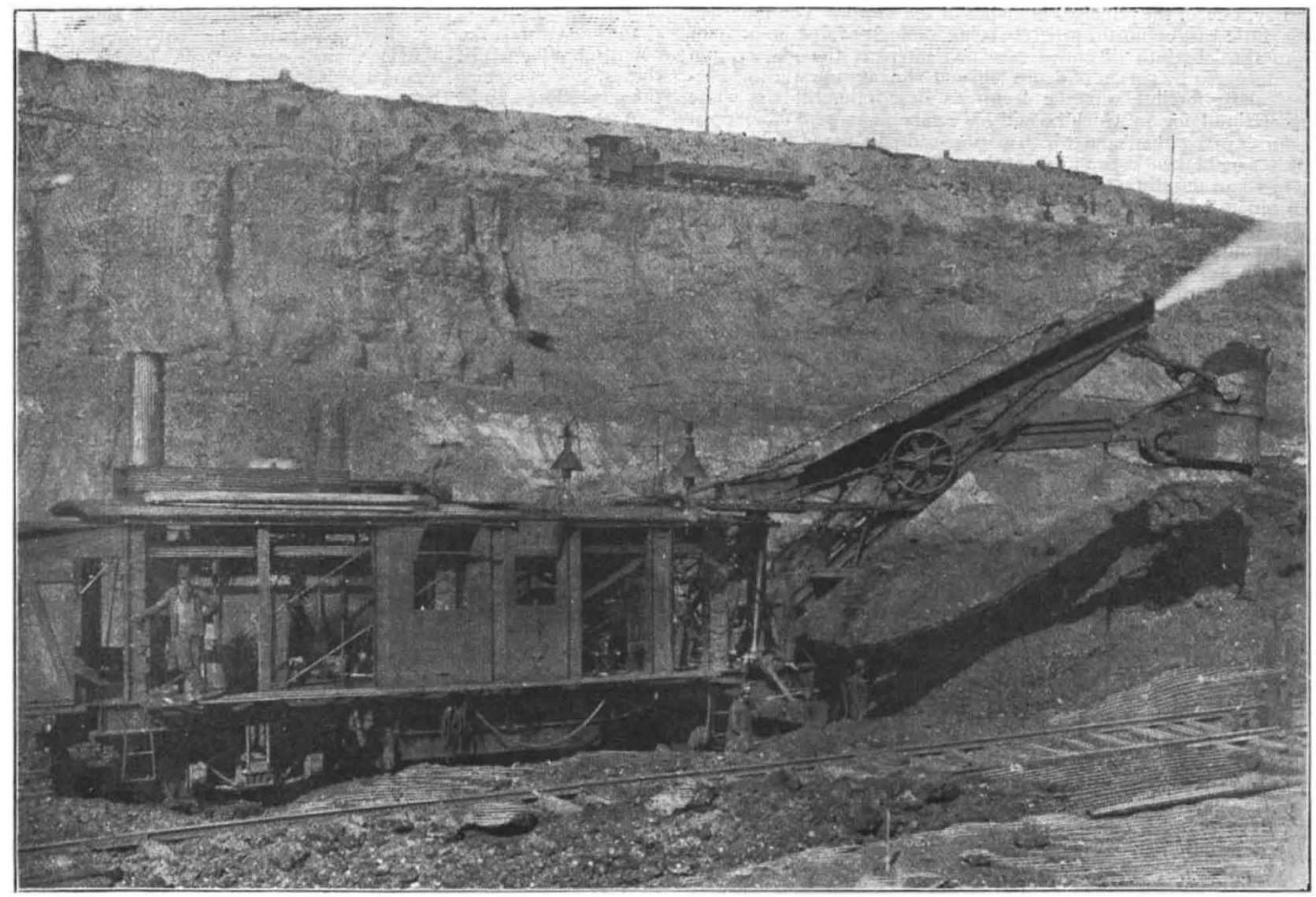

Oliver Iron Mine, showing a face of ore 50 feet high.

trict, and during that time up to January I, I897, the total output was as follows :-

\begin{tabular}{lcccr}
$\quad$ Range. & & First year. & & \multicolumn{1}{c}{ Tons. } \\
Marquette & $\ldots$ & 1856 & $\ldots$ & $46,538,187$ \\
Menominee & $\ldots$ & 1880 & $\ldots$ & $\mathbf{2 2 , 9 9 4 , 4 2 8}$ \\
Gogebic & $\ldots$ & 1884 & $\ldots$ & $20,788,787$ \\
Vermilion & $\ldots$ & 1884 & $\ldots$ & $9,220,235$ \\
Mesabi & $\ldots$ & I892 & $\ldots$ & $8,074,583$ \\
Miscellaneous & $\ldots$ & $\ldots$ & $\ldots$ & 2,320 \\
\multicolumn{6}{c}{ Total production to date } & $\ldots$ & I07,618,540
\end{tabular}

According to the official statistics, the production in 1896 was as follows :-

1 "The Lake Superior Iron-ore Region." By Horace V. Winchell. (Excerpt from the Transactions of the Federated Institution of Mining Engineers, 1897.)

$$
\text { NO. } 1481 \text {, vOL. } 57]
$$

The principal theories are (I) the obsolete one that the ores are of eruptive origin; (2) that they are mechanical sediments; and (3) that they are of chemical origin. Under the third head, the chemical action may have been that of original precipitation, or that of replacement or segregation of chemical or clastic materials by the substitution of iron oxides. Mr. Winchell inclines to the theory of oceanic precipitation advanced by him in 1889 . He considers, however, that there is no reason to suppose that all the iron-ore deposits were formed in the same way.

From an engineering point of view, the Lake Superior region is remarkable for the manner in which labour-saving appliances are adopted for extracting the iron ore and for loading it into railway waggons and vessels. The result being that at the present time the mining cost is much below that at any previous period. Thus in 1890 , when the Iron and Steel Institute visited the Lake Superior iron mines, the average cost of mining was 5s. per ton. At the present time it is $2 s .6 d$. per ton. In most cases the methods of mining adopted are those usual in under- 
ground mines. On the Mesabi range, however, some of the largest mines are worked as open quarries, the ore being obtained by steam shovels at a cost of $7 \frac{1}{2} d$. per ton. The accompanying illustration shows the steam-shovel method of mining at the Oliver Mine on the Mesabi range. The face of iron ore is 5o feet high, and the 90-ton steam-shovel with a 21 cubic yard digger shown, is capable of loading 500 tons of ore per hour. It is difficult to over-estimate the value to the United States of the discovery of ore in the Mesabi Range. A producer for only four seasons, this district has in sight to-day nearly $400,000,000$ tons of better ore than the average used in the United States, and perhaps 200,000 tons of ore containing 60 per cent. of iron, 0.06 per cent. of phosphorus, and 10 per cent of moisture. Indeed, Mr. Winchell thinks that it is not unreasonable to assert that the range will produce $500,000,000$ tons of ore before it is abandoned.

At the present time the cost of a ton of Mesabi ore laid down at a Lake Erie dock is made up of the following items :-

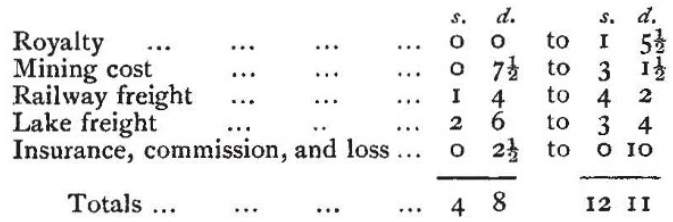

There is probably no mine which has all the minimum costs, and it is evident that prices may go still lower without shutting up enough mines to produce a scarcity of ore. Mr. Winchell appends to his valuable paper a carefully compiled bibliography, tables of analyses, and statistics of shipments for the past fortyone years. BenNetT H. BRough.

\section{UNIVERSITY AND EDUCATIONAL INTELLIGENCE.}

CAMBRIDGE.-The following is the speech delivered on March Io by the Public Orator, Dr. Sandys, in presenting, for the honorary degree of Doctor in Science, Prof. Wilhelm Pfeffer of Leipzig, Croonian Lecturer of the Royal Society, 1898 :-

Veris adventu iam propinquo, dum terra gaudet, dum caelum avet nitescere, et arbores frondescere, nihil auspicatius ducimus quam veris quasi praenuntium quendam trans maria advectum verbis bene ominatis salutare. Salutamus praeceptorem insignem, qui rerum naturae pulcherrimam nactus provinciam, discipulos ex omni orbis terrarum parte affluentes docet, qua lege lilia crocique calyces suos explicent ; quo admonitu flores, alii solis calore, alii solis lumine adducti, se aperiant; arte quali mimosa tactum etiam mollissimum reformidet frondesque teneras in sese contrahat ; artificio quam admirabili etiam vites, natura caducae, claviculis suis adminicula quaedam tamquam manibus complectantur, et quasi animantes a terra sese altius erigant. Quam dilucide demonstrat, quicquid terra gignit, secundum ea quorum in medio vivit, velut ipsos animantes, naturam suam sensim variare ac mutare. Idem neque per membranam tenuissimam aquae sorbendae rationem, quae osmosis dicitur, neque cellularum motum, qui chemotaxis nuncupatur, inexploratum reliquit. Etiam animalium minutissimorum quae bacteria nominantur motus varios quam subtiliter moderatur, et in ipsum exitium quam insidiose pellicit. Nuper a Societate Regia Londinensi in Britanniam vocatus, propediem (nisi fallor) ostendet, in eis rebus quas terra gignit, quinam sit ipse motus fons et origo; quo potissimum modo sucus ipse quem e terra trahunt, spiritus ipse quem e caelo hauriunt, quasi vim quandam mittat liberam, unde motuum inter se diversorum varietas tam magna exoriatur. Quid est in his omnibus, Academici, (ut Ciceronis utar verbis) "quid est, in quo non naturae ratio intellegentis appareat"?

Praesento vobis scientiae botanicae praeceptorem illustrem, Professorem Lipsiensem, Willelmum Pfeffer.

Mr. William Houldsworth, Rozelle, Ayr, has just intimated his intention of presenting to the University of Glasgow a sum of $5600 \%$., so invested as to yield an annual income of $150 l$., in order to endow a research studentship in connection with the Faculty of Science. The sum of $120 \mathrm{l}$. is to be paid annually to the research student on the foundation, the remainder to be used to defray laboratory expenses and materials in connection with his work, and the fees of such science classes as he may attend. To be eligible for appointment candidates must have studied at least two years in the University of Glasgow, and the appointment is to be made in the manner iaid down by the ordinance regarding research students and fellows. The period of tenure is to be two years, during which the holder must prosecute research studies in the Natural Philosophy department with diligence and regularity. Mr. Houldsworth has taken this method of showing his interest in the welfare of the University and the advancement of science, and his recognition of the distinguished services rendered to scientific research by Lord Kelvin during a professorship of fifty years.

THE London University Commission Bill passed through Committee of the House of Lords on Thursday last. The Duke of Devonshire announced that the names of the Commissioners were the same as those in the Bill of last year with one exception, and were as follows :-Lord Davey (chairman), the Bishop of London, Sir William Roberts, Sir Owen Roberts, Prof. Jebb, M.P., Prof. Michael Foster, and Mr. E. H. Busk (chairman of Convocation). It was agreed that the powers of the Commissioners should continue till the end of 1899 instead of 1898 . With the object of securing for the Agricultural College of Wye, established by the County Councils of Surrey and Kent, the advantages derivable under the Bill, Lord Stanhope moved an amendment to the clause referring to the powers and duties of the Commissioners, and he was supported by Lord Ashcombe and Lord Thring. The amendment was not pressed on a promise being given by the Duke of Devonshire that if it were found to be possible without injuriously disturbing the compromise embodied in the Bill he would endeavour on the report to insert words to meet the claims of Wye College.

RePlying to a question asked by Lord Norton in the House of Lords on Thursday last, the Duke of Devonshire said he hoped the Bill of the Government relating to secondary education would be introduced after Easter. He added: "It is not, and never has been, the intention of the Government to do any. thing in the nature of what may be called establishing secondary education all over the country. Any measure which we propose will be solely for the purpose of organising in a better way that which already exists, and, possibly, for supplementing it to a certain extent. That what is being done by county authorities, or municipal bodies, or private individuals is something to be done by the Government, is not an idea which has ever been entertained by the Government. No doubt a certain amount of the $800,000 /$. which has been given to be principally expended on technical education may have been at the outset misapplied, and perhaps a certain portion of it has been wasted; but, on the other hand, I believe that a very large portion of it is now being most usefully employed, and with very great advantage, to the various localities. It is not dependent entirely upon the will and pleasure of the County Councils. Almost every County Council has, for the purpose of administering this grant, estab. lished an educational committee, which does not usually consist solely of members of the County Council, or need not consist solely of members of County Councils. Those bodies are gradually acquiring a great deal of experience, and I believe that in a great many centres they are at present doing very valuable work."

\section{SCIENTIFIC SERIALS.}

In the January number of the Quarterly Journal of Micro. scopical Science, Mr. E. A. Minchin gives a valuable addition to our knowledge of asconid sponge morphology in a paper on the origin and growth of the triradiate and quadriradiate spicules in the family Clathrinidæ. Mr. Minchin here produces full histological evidence of his discovery of the composite origin of these two kinds of spicules; he shows that the triradiate spicules are formed by trios of dermal cells which immigrate from the epithelium to the interior; by the division of each cell a sextet is formed, and the spicule appears with each of its rays corresponding to two sister cells of the sextet. With regard to the quadriradiate spicules the three basal rays develop exactly as do the triradiate spicules, but the fourth or gastral ray is secreted by a mother cell derived from a porocyte. The spicules are crysstalline as a whole, but the rays are non-crystalline so long as they are distinct from one another, and may remain so for some little time after union has taken place; the crystallisation appears

No. I 481 , VOL. 57] 